\title{
Investigating the Source of Employees' Intention to Leave: A Case on Outsourced Employees
}

\author{
Elisabet Siahaan \\ Department of Management, Faculty of Economics and Business \\ University of Sumatera Utara \\ Medan, Indonesia \\ dr.elisabethsiahaan13@gmail.com
}

\begin{abstract}
Outsourced employment system has been well-known worldwide to improve organizational performance. An organization can reduce its recruitment and employee-related costs by using the outsourcing system. However, organizations should not rely on outsourcing too much. Agency problem may rise in the outsourcing system since the organization's performance does not benefit outsourced employees. Any employee-related benefit is managed by outsourcing provider. It will be hard for outsourced employees to deal with the client. The phenomenon may invite employees' intention to leave. This study is aimed to suppress employees' intention to leave as it may create a disadvantageous situation for both the client and provider. A number of 52 outsourced employees were participated in this study. Data were gathered using selfadministered questionnaires. A correlation and path analysis were used to evaluate the proposed model. The research shows that intention to leave has a strong and significant correlation with job stress and job satisfaction. A regression analysis showed that the more stressed out the employees were, the stronger their intention to leave would get. However, the intention to leave can be reduced through their job satisfaction. There is no significant effect of employees' commitment on intention to leave. Nevertheless, commitment has a positive and significant effect towards their job satisfaction while stress does not affect it. Employees' organizational commitment becomes a great source of intention to leave through mediating effect of job satisfaction.
\end{abstract}

Keywords-Outsource, Organizational Commitment, Job Stress, Job Satisfaction, Intention to Leave

\section{INTRODUCTION}

Outsourced employment has been one of the best choices for many organizations in the business world today. According to PwC's survey [1], the main reason for using outsourced employees is the cost saving. Organization may get desired human resources without conducting a long and costly recruitment process. Indeed it is time and cost saving for the organization. Secondly, outsourced employment gives the easy access to accessibilities for talents, excellences, or even competitive advantages. Lastly, outsourcing can be a solution for better strategic benefits, such as flexibility or new market penetration.

Outsourced employment system offers time and cost efficiencies in the recruitment. The organization does not pay outsourced employees directly but their outsourcing service provider, thus many of employees' benefits are also shifted to the provider. The provider is also responsible to develop their career and talent to satisfy organizations. Today, many organizations have been using their services, especially in banking, financing, telecommunicating, manufacturing, even retail industries. However, outsourced job is limited and cannot directly affect the main business process for the organization. Commonly, outsourced employees are assigned to a lower management level, such as staff.

Managing outsourced employees becomes today's economic challenge to produce a positive contribution towards the organization. Outsourcing the employees has always been a double-edge sword for any organization. In fact, cost efficiency and accessibilities that the organization can gain from outsourcing the job also brings up the risk for the job. Outsourced job is treated as an 'outsider' from the core organization. That is why most of allowed outsourced jobs are a non-core task. As an entity that resides outside the organization, they get their own interest. Similar to the agency problem, outsourced employees may have their own 
agenda while doing their job. They should be well-managed as it is unusual that organization's policy is not in align with the employees' interest. It may trigger an intention to leave for the organization.

Intention to leave is the source of employees' turnover. Employees' turnover is widely known as the number one concern for any organization related to their productivity since early years [2]. A doubt within employees' mind and dissatisfaction with the current job invite employees' turnover. Usually, the cost of turnover is mainly related to the cost for recruiting and training new employees [3]. However, it is not occurred in outsourced employees. The main problem is affecting their productivity. As the outsourced employees hold the unique skills or talents, their work cannot be easily replaced by other works. It may result in a different quality of work and result. It is important to suppress the key of outsourced employees' intention to leave as low as possible to maintain productivity for both quality and quantity of work.

One of interesting characteristics of outsourced employees' case is their organizational commitment. As the UU no 13/2003 [4] stated, outsourced employees work for their customers but they are maintained under the outsourcing service provider. Where does their actual commitment fall for? Customer or provider? It is clear that their benefit and compensation are given from their provider, not the customer. However, not committing their work to the customer may inflict prejudice to the customer.

The significance of this work is related to:

1. identifying the correlation between job stress, job satisfaction, organizational commitment and outsourced employees' intention to leave

2. evaluating the mediating effect of job satisfaction level towards intention to leave

3. suggesting the best way to reduce outsourced employees' intention to leave

\section{LITERATURE REVIEW}

\section{Common situation of the outsourced employees in Indonesia}

In Indonesia, outsourced employment is regulated under UU No 13/2003 on article 59, 64, 65 and 66. They gain a legal status and law protection. It is clear that outsourced employees cannot be abused by the organization. They cannot be placed in a strategic position or in a dangerous environment. They work in contract. Extending the contract period may give an opportunity to outsourced employees to be promoted as regular employees in the organization.
In accordance with PwC survey, over $70 \%$ of organizations seek outsourced employees for their talents. It has a snowball effect to other employees' learning activities. Their organization can be benefitted to become more mature and ready for the expansion plan. However, it also comes with a challenge. Whenever a project fails, it is $90 \%$ the outsourcing service provider who is blamed for the incompetence while outsourced employees think that it is due to poor collaboration with their customers.

Job satisfaction becomes a number one of the biggest problems within Indonesia's outsourced employees. Many organizations seek for a cost efficiency while outsourcing their employees. Even if they do the work excellently, they do not gain any significant benefit. However, a failure is meant to take the blame. Working in a new environment also means a challenge for employees who are vulnerable to dissatisfaction especially those who are under an unpleasant interpersonal relationship.

\section{The employees' intention to leave}

Grant et al. [5] stated that intention to leave (also called as turnover intention) is related to employees' attitude and behaviour towards a possibility to resign from the current job voluntarily. The stronger the intention is, the higher the possibility to leave the organization. It is clear that this intention leads to employees' turnover. However, many cases also show that strong intention does not end with a turnover, for example the need for stability of work which forces them to work.

In accordance with Mobley [6], the level of employees' intention to leave can be measured through their behaviour at work. The first level of intention to leave can be identified as the employees seek for another job which is considered as a better job from the current one. Hartono [7] identified a more expulsive characteristic. A high intention to leave may be shown through the increase of abstains, unmotivated to work, intentionally break the code at work, and deviated behaviour from the usual workday.

Mahdi et al. [8] stated that there are three main phases of intention to leave: thinking, seeking and quitting. It is important to identify how far that employees' intention to leave has already taken the stage off. Almigo et al. [9]'s study states that intention to leave may be caused by their job satisfaction and their organizational commitment. Elhamahanian et al. [10] showed that stress at work among nurses triggers their intention to leave.

\section{The relationship between job stress and intention to leave}

Stress is commonly occurred in any activity. People's stress resistance towards the stress itself is different one with another. Burgess [11] claimed that stress is a 
problematic state that can reduce productivity and people's health. Facing stress is inevitable as it is occurred on any activity we take [12]. People consider that job stress is the biggest problem in their life and it may trigger their intention to quit the stressful job. Intention to leave is a state that people are still willing to leave the job but have not actually left it yet [10]. The study also shows a positive relationship between job stress and intention to leave.

Robbins and Judge [13] stated that stress will affect people's behaviour at work which also affects their productivity, turnover, abstains and accident at work. Stress directly affects people's emotion and their thought. It will be implied on their voluntary turnover. Excessive stress that exceeds people's resistant threshold will keep on pressing the person and build a perception to quit the organization, that is the intention to leave. Theoretically, job stress ends in people's intention to leave.

\section{Job satisfaction to reduce intention to leave}

Robbins and Judge [13] explained that job satisfaction is related to positive attitude towards the job itself. Basically, job satisfaction is different from each employee even in the same working environment. Job satisfaction differs in individual level as they may embrace different value. However, common people will be satisfied with their job if their job result is in align with their expectation from that job. For example, a desirable compensation, praise, authority or acknowledgement.

Job satisfaction comes with its bipolar, dissatisfaction. The negative consequence while evaluating the result of one's job is dissatisfaction. If the result of the job is below their expectation, it will trigger the dissatisfaction. Many researches show a negative relationship between job satisfaction and intention to leave. A satisfied employee will be more likely to keep on their job as a happy work brings out a happy life. In contrast, a dissatisfied one will soon seek for another job to look for a better job for himself or herself.

Masum et al. [14] showed an empiric evidence that job satisfaction will reduce employees' intention to leave. Their work also states that a dissatisfied nurse will be more likely to quit his or her job which causes a shortage at human power. Thus it is important to identify the source of job satisfaction and keep employees happy with their current job.

\section{Organizational commitment and intention to leave}

Mowday et al. [15] started a discussion towards organizational commitment and developped stages of organizational commitment. Organizational commitment is related to how people connect themselves to the objective of organization. They may align organizational goals as their own. Thus, organization's successfulness will be considered as their success factor.

Many of previous works show a similarity of dedication and commitment such as Greenhaus's work [16]. The problem rises in outsourced employees. It is unclear how to evaluate their commitment, whether it is to the provider or customer. However, it is an important fact that they should show commitment towards their job as requested by their customer.

Intention to leave as the people's tendency to quit the current job may be affected by organizational commitment [17]. Yildrim et al. [18]'s recent work shows that employees' organizational commitment has a weak but significant negative correlation with their intention to leave.

\section{Job stress and job satisfaction}

Hans et al. [19] concluded that both job stress and job satisfaction are important issues that should be well managed. They concluded that both are important to keep the organization's performance. However, too much stress may reduce their job satisfaction. Riaz's study [20] concludes that job stress has a positive impact on their satisfaction. Hard-work that builds stress is resulted as a good work that is in align with employees' expectation which brings up their satisfaction. Sometimes, stressed work may be resulted in satisfaction.

\section{Organizational commitment and job satisfaction}

The relationship between commitment and satisfaction is still inconsistent [21]. In this study, we assume that organizational commitment will trigger employees' job satisfaction level. Leite et al. [22]'s work shows that organizational commitment has a positive impact on employees' job satisfaction. As they dedicate themselves for their job, they will give their best which will result in expected way and bring up the job satisfaction.

\section{RESEARCH METHOD}

\section{Research design}

The study was conducted at PT Pertamina RU II Dumai, Riau. It was conducted from October to December 2016. The organization employed 52 outsourced employees during the research period. All outsourced employees were participated in this study.

\section{Data collection method}

The data were collected through structured interview based on self-administered questionnaires. The outsourced employees were asked for their opinions towards each 
indicator that reflected their intention to leave, job stress level, job satisfaction level, and organizational commitment.

\section{Data analysis method}

The data were analyzed by using both correlation analysis and path analysis. Firstly we ensured that the proposed model was supported by correlation analysis. Secondly we evaluated each path to find the impact towards dependent variables. Sobel test was used to evaluate its significance of mediating effect.

\section{RESULT}

The first part of this paper examined the correlation between variables to satisfy our proposed model. Pearson correlation analysis was used in this study. The result is summarized in Table 1.

TABLE 1. CORRELATION BETWEEN VARIABLES

\begin{tabular}{|c|c|c|c|c|c|}
\hline \multicolumn{6}{|c|}{ Pearson Correlations } \\
\hline & & $\begin{array}{l}\text { Intention to } \\
\text { Leave }\end{array}$ & Job Satisfaction & $\begin{array}{c}\text { Organizational } \\
\text { Commitment }\end{array}$ & Job Stress Level \\
\hline \multirow{2}{*}{ Intention to Leave } & Pearson Correlation & 1 & & & \\
\hline & Sig. (2-tailed) & & & & \\
\hline \multirow{2}{*}{ Job Satisfaction } & Pearson Correlation & $-.922 * *$ & 1 & & \\
\hline & Sig. (2-tailed) & .000 & & & \\
\hline \multirow{2}{*}{ Organizational Commitment } & Pearson Correlation & $-.926 * *$ & $.963 * *$ & 1 & \\
\hline & Sig. (2-tailed) & .000 & .000 & & \\
\hline \multirow{2}{*}{ Job Stress Level } & Pearson Correlation & $.913 * *$ & $-.874 * *$ & $-.901 * *$ & 1 \\
\hline & Sig. (2-tailed) & .000 & .000 & .000 & \\
\hline
\end{tabular}

Table 1 shows that job satisfaction strongly correlated with their organizational commitment and job stress level. The stronger their organizational commitment was, the more satisfied they would get with their job. In contrast, as their stress level rose, they would be less likely satisfied with their job.

Table 1 also shows that intention to leave strongly correlated with our suggested predictor. Their intention to leave might be reduced as they got satisfied or had a high level of organizational commitment. However we should pay attention towards the stress level. As the level rose, it would be more likely to trigger outsourced employees' intention to leave.

The second part of our paper evaluated the path analysis of each variable. Thus, we divided the model analysis under two sub-models. The first sub-model would evaluate the effect of organizational commitment and job stress level on job satisfaction. The other model would evaluate the effect of job satisfaction, organizational commitment, and job stress level to intention to leave. Job satisfaction took the role as a mediator in the model. Table 2 summarizes the regression analysis for both models.

\section{TABLE 2. REGRESSION ANALYSIS}

\begin{tabular}{|c|c|c|c|c|c|c|}
\hline \multirow{2}{*}{\multicolumn{2}{|c|}{ Model }} & \multicolumn{2}{|c|}{ Unstandardized Coefficients } & \multirow{2}{*}{$\begin{array}{c}\text { Standardized Coefficients } \\
\text { Beta }\end{array}$} & \multirow{2}{*}{$\mathbf{t}$} & \multirow{2}{*}{ Sig. } \\
\hline & & $\mathbf{B}$ & Std. Error & & & \\
\hline \multicolumn{7}{|c|}{ Dependent Variable: Job Satisfaction } \\
\hline \multirow[t]{3}{*}{ Model 1} & (Constant) & 2.998 & .555 & & 5.400 & .000 \\
\hline & Job Stress Level & -.472 & .093 & -.552 & -5.051 & .000 \\
\hline & Organizational Commitment & .391 & .103 & .415 & 3.803 & .000 \\
\hline
\end{tabular}


TABLE 2. Cont

Dependent Variable: Intention to Leave

\begin{tabular}{|l|l|c|c|c|c|c|}
\hline Model 2 & (Constant) & 3.108 & .535 & & 5.812 & .000 \\
\cline { 2 - 7 } & Organizational Commitment & -.164 & .161 & -.192 & -1.018 & .314 \\
\cline { 2 - 7 } & Job Stress Level & .379 & .099 & .403 & 3.838 & .000 \\
\cline { 2 - 7 } & Job Satisfaction & -.356 & .155 & -.385 & -2.290 & .026 \\
\hline
\end{tabular}

Adjusted R-squared $=0.895 ; \mathrm{F}=145.7($ Sig 0.000)

Table 2 shows that both organizational commitment and job stress significantly affected the job satisfaction. Job stress had a negative effect towards job satisfaction while organizational commitment had a positive effect. The effect of job stress was higher than organizational commitment in predicting employees' job satisfaction. The model explained $88.6 \%$ variance of job satisfaction.

In accordance with the result of model 2, organizational commitment's effect was not significant to predict their intention to leave. However, both job satisfaction and job stress level significantly affected the intention to leave. It was important to keep the job stress level low and keep outsourced employees happy with their job. The second model explained $89.5 \%$ variance of intention to leave.

Sobel test analysis showed that even though organizational commitment could not predict the intention to leave significantly, the effect through job satisfaction was significant. Both organizational commitment and job stress could be mediated through job satisfaction. The effect was fully mediated for organizational commitment and partially mediated for job stress level.

\section{DISCUSSION}

Our study showed that the only proposed predictor that cannot significantly predict intention to leave is organizational commitment. We have already stated that the current organizational commitment for outsourced employees is rather difficult to evaluate. They kept on whining between the provider or customer. We believe that as outsourced employees they dedicate their work for both. However, it makes them unclear whether to dedicate more on the customer. The customer (PT Pertamina) does not hold many responsibilities towards their outsourced employees. It is regulated that their benefit and compensation are managed by their provider. Whether they give dedication for the job is not significantly affecting their intention to leave.

Even though organizational commitment does not significantly affect outsourced employees' intention to leave directly, however, it has positive and significant impact to job satisfaction level. The more they dedicate themselves for the customer, the more they can enjoy the current job. Our interview highlighted that their interaction among employees, including the customer became better and healthier as they committed themselves to the customer. The significant indirect effect of organizational commitment on intention to leave happens while it is mediated by job satisfaction. We have already stated that directly, there is no effect of organizational commitment on intention to leave as it is a different matter. However, as long as the organizational commitment can produce satisfaction at work, their intention to leave will also be reduced.

Job stress is really the most important aspect to keep in mind. It acts as the most significant and biggest impact for both job satisfaction and intention to leave. The previous study (Riaz et al., 2016) showed that stress would bring out satisfaction. Challenging work builds up stress but keeps the employees happy. They seek for challenges. It is not working for our participant. Stress should be controllable. In fact, it is needed for growth. However, too much stress as more than people's stress resistant value will bring up a trouble. They will be less satisfied with the work and it will trigger their intention to leave. It is advisable that stress should be maintained at the low level for outsourced employees.

\section{CONCLUSION}

In align with our objectives, we found that there is a significant correlation between the proposed variables. Job satisfaction significantly correlated with organizational commitment and job stress. Intention to leave significantly correlated with organizational commitment, job stress, and job satisfaction. The correlation analysis concludes that a high level of job stress will be more likely increase outsourced employees' intention to leave and decrease their job satisfaction. Keeping the employees happy is the key to reduce their intention to leave. Regression analysis showed that organizational commitment of outsourced employees was not significant to affect the intention to leave directly. However if it can help employees to be happier with the work, it will reduce their intention to leave. 
Based on our result it is highly recommended for organizations to outsource their employees, it is important to keep them satisfied with their work. Even though most part of managing outsourced employees are managed by their provider, the customer also has to take initiative to measure their level of job satisfaction and act accordingly. Indeed outsourced employees are the external aspect of organization, however keeping their work also helps the organization for a long term.

\section{REFERENCES}

[1] PricewaterhouseCoopers (Pwc), "Outsourcing comes of age: The rise of collaborative partnering", in Global Outsourcing, 2007

[2] G.S. and Kim, S.Y. Kim, "Influences of job stress and burnout on turnover intention of nurses", in Journal of Korean Academy of Nursing Administration, 16(4), 507-516, 2010

[3] L.J. Mullins, Management and organisational behaviour, 7th Edition. New Jersey: Prentice Hall, 2005.

[4] Presiden Republik Indonesia, Undang-Undang Republik Indonesia Nomor 13 Tahun 2003 tentang Ketenagakerjaan, 2003

[5] K. Grant, D.W. Cravens, G.S. Low, and W.C. Moncrief, "The role of satisfaction with territory design on the motivation, attitudes, and work outcomes of sales people", in Journal of The Academy of Marketing Science, Volume 29, 165-178, 2001

[6] W.H., Mobley, R.W. Griffeth, H.H. Hand, and B.M. Meglino, "Review and conceptual analysis of the employee turnover process" in Psychological Bulletin 86, Volume 3, 493-522, 2001

[7] Hartono, Manajemen Sumber Daya Manusia, Jakarta: PT Bumi Aksara, 2002

[8] A.F. Mahdi, M.Z. Zin, M.R. Nor, A.A Skat, and A.S. Naim, "The relationship between job satisfaction and turnover intention", in American Journal of Applied Sciences, Volume 9,1518-1526, 2012

[9] N. Almigo, A.W. Khan, and H. Hamzah, "Coach turnover, tendency review of job satisfaction and organizational commitment at program in the national service" in Science Movement and Health, Volume 14, 521-525, 2014

[10] Elhamahanian, A. Mirzaei, A.S. Fard, "The study of correlation between job stress and turnover intentions among the operation room nurses in selected hospital of Tehran University of Medical Science", in Acta Medica Mediterranea, 1045-1050, 2016

[11]L. Burgess, F. Irvin, A. Wallymahmed, "Personality stress and coping in intensive care nurses: A descriptive exploratory study", in Nursing in Critical Care, Volume 15, 129-168, 2010
[12] J.K. Mojoyinola, "Effect of job stress on health, personal and work behavior of nurses in public in Ibadan Metropolis, Nigeria", in Ethno Med, Volume 2, 143-148, 2008

[13] S.P. Robbins, and T.A. Judge. Organizational Behavior Fifteenth Edition, New York: Pearson Prentice Hall, Ebook, 2013

[14] A.K.K. Masum, M.A.K. Azad, K.E. Hoque, L.S. Beh, P. Wakne, and O. Arslan, "Job satisfaction and intention to quit: An empirical analysis of nurses in Turkey", in PeerJ, Published Online, 2016

[15] R.T. Mowday, R.M. Steers, and L.W. Porter, "The measurement of organizational commitment", in Journal of Vocational Behavior, Volume 14, 224-247, 1979

[16] J.H. Greenhaus, "An investigation of the role of career salience", in Journal of Vocational Behavior, Volume 1, 209-216, 1971

[17] J.P. Slattery, and T.T.R. Selvarajan, "Antecedents to temporary employee's turnover intention", in Journal of Leadership and Organizational Studies, Volume 12, 53-66, 2005

[18] M. Yildirim, A. Acar, U. Bayraktar, O. Akova, "The effect of organizational commitment and job commitment to intention to leave of employment: A research in hotel management", International Journal of Business and Social Science, Volume 6, 128-137, November 2015

[19]D.A. Hans, D.S. Mubeen, and M.S. Saadi, "A study on work stress and job satisfaction among headmasters: A case study of bilingual schools in Sultanate of Oman - Muscat" in Journal of Sociological Research, Volume 5, 40-46, 2014

[20] M. Riaz, N. Ahmad, M. Riaz, G. Murtaza, T. Khan, and H. Firdous, "Impact of job stress on employee job satisfaction", in International Review of Management and Business Research, Volume 5, 1370-1382, December 2016

[21] M. Riketta, and R. VanDick, "Commitment's place in the literature", In Commitment in organizations: accumulated wisdom and new directions, 69-95, New York: Routledge Academic, 2009

[22]N.R.P Leite, A.C.A Rodrigues, and L.G. Alburquerque, "Organizational commitment and job satisfaction: What are the potential relationships?", in Brazillian Administration Review, Volume 11, 476495, 2014 